\title{
Nonionic Surfactants Enhancing Bactericidal Activity at Their Critical Micelle Concentrations
}

\author{
Seiichi Tobe ${ }^{1 *}$, Toshiaki Majima², Hirohiko Tadenuma ${ }^{1}$, Tomonari Suekuni², \\ Kenichi Sakai ${ }^{3}$, Hideki Sakai ${ }^{3}$ and Masahiko Abe $^{3}$ \\ ${ }^{1}$ Fabric-care Research Laboratories, Research \& Development Headquarters, Lion Corporation, 7-2-1 Hirai, Edogawa-ku, Tokyo, 132-0035, \\ JAPAN. \\ ${ }^{2}$ Functional Materials Science Research Laboratories, Research \& Development Headquarters, Lion Corporation, 7-2-1 Hirai, Edogawa-ku, \\ Tokyo, 132-0035, JAPAN. \\ ${ }^{3}$ Department of Pure and Applied Chemistry in Faculty of Science and Technology and Research Institute for Science and Technology, Tokyo \\ University of Science, 2641 Yamazaki, Noda, Chiba, 278-8510, JAPAN.
}

\begin{abstract}
Bactericidal activities of benzalkonium chloride [also known as alkyldimethylbenzylammonium chloride (ADBAC)] containing nonionic surfactants such as methyl ester ethoxylates (MEE) with the alkyl group C8-C14 and oxyethylene (EO) group of average adduct number 3-15 were measured against Escherichia coli and Staphylococcus aureus. Sample solutions containing MEE in the vicinity of the critical micelle concentration exhibited a dramatic decrease in viable bacterial counts. MEE with an alkyl group of C12 and an oxyethylene group of lower adduct number exhibited little viable bacterial counts than those having higher EO adduct numbers. MEE with reduced EO adduct numbers increased fluorescence intensity in $E$. coli using the viability stain SYTO 9. Our results show that MEE molecules with low EO adduct numbers exhibited bactericidal activity by increasing the permeability of the $E$. coli cell membrane. Sample solution containing ADBAC and MEE molecules with lower EO adduct numbers also displayed higher zeta potentials. Moreover, ADBAC molecules incorporated into micelles of MEE with lower EO adduct numbers were adsorbed onto the surface of $E$. coli, which augmented bactericidal activity.
\end{abstract}

Key words: ADBAC, bactericide, enhancement, MEE, nonionic surfactant

\section{INTRODUCTION}

Disinfection is one of the important measures for preventing infections, food poisonings, and other issues caused by bacteria. Bacterial growth is often controlled using heat, irradiation, and bactericides. Ethyl alcohol, glutaraldehyde, phenol compounds, sodium hypochlorite, iodine, cationic surfactants, such as benzalkonium chloride [also known as alkyldimethylbenzylammonium chloride (ADBAC) ] and didecyldimethylammonium chloride (DDAC), are well-known bactericides ${ }^{1)}$. The strong bactericidal activities of these agents provide reliable disinfection.

It has been known that nonionic surfactants often inhibit bactericidal activity because some cosmetics containing nonionic surfactants often show little antiseptic activity ${ }^{2)}$. The nonionic surfactant, Tween 80 , is used as a stop reagent in tests when evaluating various antiseptics ${ }^{3,4)}$. In these tests, bacteria are added to a sample solution containing bactericide where they react. After the reaction, soybean-casein digest broth with lecithin and polysorbate 80 (SCDLP) containing Tween 80 is added to the solution. Subsequently, viable bacteria are incubated on the SCDLP plates. Viable bacteria are able to grow on these plates in the presence of residual bactericides. It has been suggested that bactericides are incorporated into micelles formed by nonionic surfactant molecules such as Tween 80, and the adsorption of bactericides into the bacteria is suppressed ${ }^{5)}$. Alternatively, several nonionic surfactants show reductions in minimum inhibitory concentrations (MIC) of bactericides such as cationic surfactants ${ }^{2,6)}$. Gomi et al. reported that particular nonionic surfactants augmented bactericidal activity of DDAC ${ }^{7)}$.

Certain bactericides are included in many recent types of cleaning products and their bactericidal ability has great value. Nonionic surfactants are also included in cleaning products to increase the washing performance ${ }^{8,9)}$. Methyl ester ethoxylates (MEE) are well-known ester type nonionic surfactants that have superior washing performance ${ }^{10,11)}$.

*Correspondence to: Seiichi Tobe, Fabric-care Research Laboratories, Research \& Development Headquarters, Lion Corporation, 7-2-1 Hirai, Edogawa-ku, Tokyo, 132-0035, JAPAN.

E-mail: seto@lion.co.jp

Accepted August 25, 2014 (received for review July 22, 2014)

Journal of Oleo Science ISSN 1345-8957 print / ISSN 1347-3352 online

http://www.jstage.jst.go.jp/browse/jos/ http://mc.manusriptcentral.com/jjocs 
MEE : $\mathrm{CH}_{3}\left(\mathrm{CH}_{2}\right)_{(\mathrm{n}-2)}-\mathrm{COO}-\left(\mathrm{C}_{2} \mathrm{H}_{4} \mathrm{O}\right)_{m}-\mathrm{CH}_{3}$

\section{$\mathrm{AE}: \mathrm{CH}_{3}\left(\mathrm{CH}_{2}\right)_{(\mathrm{n}-1)}-\mathrm{O}-\left(\mathrm{C}_{2} \mathrm{H}_{4} \mathrm{O}\right)_{m}-\mathrm{H}$}

Fig. 1 Chemical structures of MEE and AE. $\mathrm{n}$ : carbon number, m: EO average adduct number.

As shown in Fig. 1, they have alkyl groups as their hydrophobic group and oxyethylene (EO) groups as their hydrophilic group as well as general industrial nonionic surfactants, alcohol ethoxylates $(\mathrm{AE})^{12)}$. MEE is synthesized not only by EO addition reaction but also by transesterification $^{13,14)}$. The EO adduct number is determined by the reaction, and each carbon number of the alkyl groups is derived from each methyl ester.

In the present study, we investigated the difference in properties of nonionic surfactants on bactericidal activity. We attempted to understand the properties of nonionic surfactants on bactericidal activity to be able to develop better cleaning products. Therefore, we synthesized MEE with various alkyl groups and EO adduct numbers and investigated the bactericidal properties of nonionic surfactants with ADBAC.

\section{EXPERIMENTAL PROCEDURES}

\subsection{Strains}

Escherichia coli NBRC3972 and Staphylococcus aureus NBRC12732 were obtained from the National Institute of Technology and Evaluation Biological Resource Center (Chiba, Japan).

\subsection{Reagents}

As shown in Table 1, MEE was synthesized by transesterification or EO addition reaction according to commonly used procedures ${ }^{13)}$, and more than $96 \%$ of their purities were determined by quantitative nuclear magnetic resonance. Methyl esters were obtained from Lion Chemi- cals Division(Tokyo, Japan) and alkyl glycol ethers were obtained from Nippon Nyukazai (Tokyo, Japan) as raw materials. Each AE, EMALEX 703 (alkyl group: C12; average EO adduct number: 3), EMALEX 715 (alkyl group: C12; average EO adduct number: 15), and EMALEX 750 (alkyl group: C12; average EO adduct number: 50) were obtained from Nihon Emulsion(Tokyo, Japan). Their critical micelle concentration $(\mathrm{CMC})$ values were estimated between 0.04 $\mathrm{mM}$ and $0.1 \mathrm{mM}$, according to reference data of the AE with an alkyl group of $\mathrm{C} 12^{15)}$. ADBAC was obtained from Wako Pure Chemical Industries (Osaka, Japan), and the $\mathrm{CMC}$ of ADBAC was determined at $2.1 \mathrm{mM}$. SYTO 9 was obtained from Life Technologies (CA, USA) ${ }^{16)}$, and propidium iodide(PI) was obtained from Dojindo Laboratories (Tokyo, Japan) ${ }^{17}$. Other chemicals were of analytical grade and purchased from commercial companies.

\subsection{Measurement of $\mathrm{CMC}$}

CMC values of MEE and ADBAC were evaluated at $30^{\circ} \mathrm{C}$ using isothermal titration calorimetry (VP-ITC, GE Health(are, Uppsala, Sweden) ${ }^{18)}$.

\subsection{Measurement of bactericidal activity}

Bactericidal activity was measured according to a European standardized test (EN 1040), and a modified version of the preservative effectiveness tests listed in the Japanese Pharmacopoeia, Sixteenth Edition ${ }^{19,20)}$. Each strain was inoculated onto tryptic soy agar plates (Becton, Dickinson and Company, NJ, USA) and incubated twice at $37^{\circ} \mathrm{C}$ for $24 \mathrm{~h}$. Bacterial cells were suspended in sterile water, with an optical density at $660 \mathrm{~nm}\left(\mathrm{OD}_{660 \mathrm{~nm}}\right)$ of 30 (cell suspension). Next, $0.01 \mathrm{~mL}$ of cell suspension was added to 10 $\mathrm{mL}$ of each sample solution and the reaction was performed at $25^{\circ} \mathrm{C}$ for $10 \mathrm{~min}$. Reaction mixture was diluted by 10-fold serial dilutions with SCDLP(Nihon Pharmaceutical, Osaka, Japan). The serial dilutions were added to the SCDLP agar solution, which was maintained at $45^{\circ} \mathrm{C}$, and incubated at $37^{\circ} \mathrm{C}$ for $24-48 \mathrm{~h}$. After incubation, viable bacterial counts (colony formation units, CFU) were determined by serial dilution and colony counts on SCDLP agar plates.

Table 1 Characteristics of each MEE.

\begin{tabular}{llcccc}
\hline $\begin{array}{c}\text { Abbreviations } \\
(\mathrm{CnEOm})\end{array}$ & Alkyl groups & $\begin{array}{c}\text { Average EO } \\
\text { numbers }\end{array}$ & \multicolumn{2}{c}{$\mathrm{CMC}$} & Preparation methods \\
\hline $\mathrm{C} 8 \mathrm{EO} 3$ & octyl, C8 & 3 & 7.5 & $\mathrm{mM}^{*}$ & Transesterification \\
$\mathrm{C} 10 \mathrm{EO} 4$ & decyl, C10 & 4 & 0.7 & $\mathrm{mM}$ & Transesterification \\
$\mathrm{C} 12 \mathrm{EO} 5$ & dodecyl, C12 & 5 & 0.09 & $\mathrm{mM}$ & Transesterification \\
$\mathrm{C} 12 \mathrm{EO} 15$ & dodecyl, C12 & 15 & 0.2 & $\mathrm{mM}$ & EO addition \\
C14EO6 & tetradecyl, C14 & 6 & $0.007 \mathrm{mM}$ & EO addition \\
\hline
\end{tabular}

*: Estimated from the $\mathrm{CMC}$ of $\mathrm{AE}$ with alkyl group of $\mathrm{C} 8$ and average $\mathrm{EO}$ adduct number of three ${ }^{15)}$. 


\subsection{Measurement of fluorescence intensity}

Two milliliters of sample solution containing $0.25 \mu \mathrm{M}$ SYTO 9 and MEE was added to a cell in a fluorescence spectrophotometer (F-2700, Hitachi High-Technologies, Tokyo, Japan). Next, $0.02 \mathrm{~mL}$ of $E$. coli cell suspension adjusted to an $\mathrm{OD}_{660 \mathrm{~nm}}$ of 30 was added in a stirred sample solution and the reaction was performed at $25^{\circ} \mathrm{C}$. Fluorescence intensity of SYTO 9 was measured at excitation wavelength $(\lambda \mathrm{ex}=480 \mathrm{~nm})$ and emission wavelength $(\lambda \mathrm{em}$ $=500 \mathrm{~nm})$ at 0.5 -s intervals. Other sample solutions containing $0.75 \mu \mathrm{M} \mathrm{PI}$ and MEE were also measured in the same manner at $\lambda \mathrm{ex}=490 \mathrm{~nm}, \lambda \mathrm{em}=635 \mathrm{~nm}$.

\subsection{Measurement of zeta potential}

Zeta potentials of sample solutions containing MEE and ADBAC were measured using zeta potential and particle size analyzer ELSZ-1000 (Otsuka Electronics, Osaka, Japan; measurement accuracy: $0.01 \mathrm{mV})^{21)}$.

\subsection{Measurement of ADBAC transferred to bacterial cells}

E. coli was inoculated onto tryptic soy agar plates and incubated twice at $37^{\circ} \mathrm{C}$ for $24 \mathrm{~h}$. Cells grown on two plates were suspended in $20 \mathrm{~mL}$ of sterile water, and centrifuged at 5,000 rpm for $5 \mathrm{~min}$. Next, the supernatant was removed, the pellet was suspended in sterile water, and the suspension was centrifuged again. The pellet was suspended in sterile water, corresponding to 50 of $\mathrm{OD}_{660 \mathrm{~nm}}$. A volume $1 / 50$ of the cell suspension was added to each sample solution and the reaction was performed at $25^{\circ} \mathrm{C}$ for $10 \mathrm{~min}$; the sample was centrifuged at 5,000 rpm for 5 $\mathrm{min}$. The supernatant was filtrated using a $0.22-\mu \mathrm{m}$ filter. The concentration of ADBAC in the filtrated solution was measured using HPLC. The conditions were as follows: ODS column, $\mathrm{MeOH} / 0.1 \mathrm{M} \mathrm{NaClO}_{4}=75 / 25$ (in volume) as the developing solvent, current speed of $1 \mathrm{~mL} / \mathrm{min}$. Concentration of ADBAC was measured by absorbance at 254 nm. ADBAC that transferred to cells was calculated using the following equation:

Transferred $\mathrm{ADBAC}(\mathrm{mM})=$ concentration of $\mathrm{ADBAC}$ added to the sample $(\mathrm{mM})$ - concentration of ADBAC filtrated solution of each sample $(\mathrm{mM})$

\section{RESULTS AND DISCUSSION}

\subsection{Bactericidal activity with MEE}

E. $\operatorname{coli}(7.4 \log \mathrm{CFU} / \mathrm{ml})$ was added to each sample solution containing $3 \mu \mathrm{M}$ ADBAC and MEE, and then viable bacterial counts of $E$. coli were measured. As shown in Fig. 2 , reference solution containing $3 \mu \mathrm{M}$ ADBAC without MEE showed viable bacterial counts of $7.0 \log \mathrm{CFU} / \mathrm{mL}$ against initial counts of $7.4 \log \mathrm{CFU} / \mathrm{mL}$. Each sample solution containing $3 \mu \mathrm{M}$ ADBAC and MEE exhibited a reduction in viable bacterial count compared with the reference

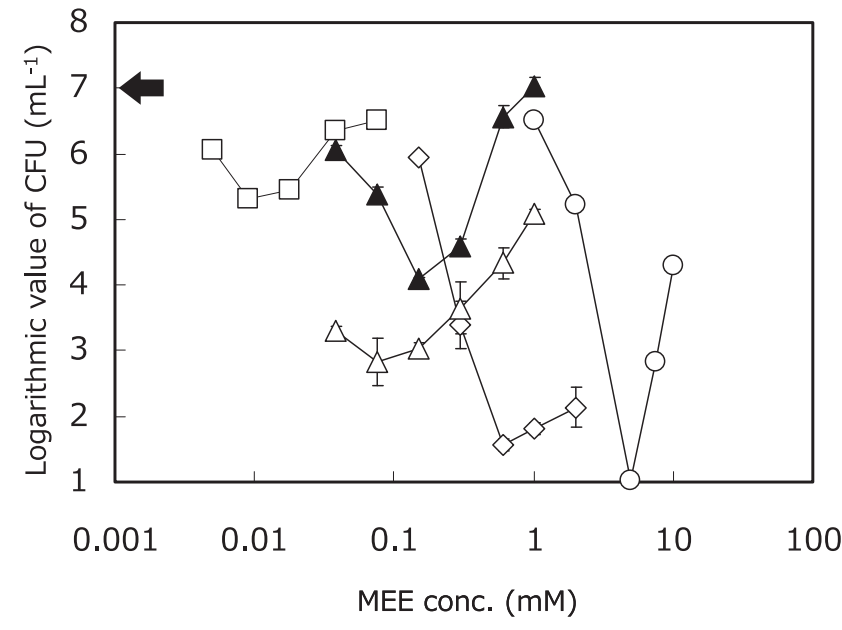

Fig. 2 Reduction in viable bacterial counts in a solution containing $3 \mu \mathrm{M}$ ADBAC and variable concentration of MEE with $7.4 \log \mathrm{CFU} / \mathrm{mL}$ of $E$. coli. $\bigcirc: \mathrm{C} 8 \mathrm{EO} 3, \diamond: \mathrm{C} 10 \mathrm{EO} 4, \triangle: \mathrm{C} 12 \mathrm{EO} 5, \boldsymbol{\Delta}$ : C12EO15, $\square$ : C14EO6. Arrow represents viable bacterial counts of $7.0 \log \mathrm{CFU} / \mathrm{mL}$ in a solution containing $3 \mu \mathrm{M}$ ADBAC without MEE.

solution. Substantial decreases were shown in the vicinity of CMC of each MEE. The reduction trends indicated that $\mathrm{C} 8 \mathrm{EO} 3(5 \mathrm{mM})>\mathrm{C} 10 \mathrm{EO} 4(0.6 \mathrm{mM})>\mathrm{C} 12 \mathrm{EO} 5(0.075 \mathrm{mM})$ $>$ C14EO6 (0.009 mM). Decreases in the number of carbons in the alkyl chain in MEE resulted in enhancement of bactericidal activity. Other sample solutions containing ca. the CMC of MEE in the absence of ADBAC showed viable bacterial counts above $6.4 \log \mathrm{CFU} / \mathrm{mL}$. In this study, $3 \mu \mathrm{M}$ ADBAC was added to each sample solution. This concentration is much lower than the CMC of this surfactant $(2.1 \mathrm{mM})$. Therefore, micelles formed in sample solutions are mainly constructed by MEE molecules; thus, the CMC of the micelles correspond to that of MEE alone. Therefore, it is evident that the bactericidal activity of ADBAC is augmented in the vicinity of the CMC of MEE, although MEE showed weak or no bactericidal activity. It is likely that ADBAC demonstrated enhancing bactericidal activity in the absence of MEE micelles; however, incorporation of ADBAC into MEE micelles resulted in the inhibition of bactericidal activity of ADBAC.

Bactericidal activities between $\mathrm{C} 12 \mathrm{EO} 15$ and $\mathrm{C} 12 \mathrm{EO} 5$ were compared to evaluate the effects of $\mathrm{EO}$ chain length. As shown in Fig. 2, a sample solution containing C12EO5 in the vicinity of $\mathrm{CMC}(0.075 \mathrm{mM})$ revealed viable bacterial counts of $2.8 \log \mathrm{CFU} / \mathrm{mL}$, whereas that of $\mathrm{C} 12 \mathrm{EO} 15$ showed counts of $4.1 \log \mathrm{CFU} / \mathrm{mL}$. Therefore, C12EO5 exhibited a stronger reduction in viable bacterial counts than C12EO15. These results indicate that shorter EO chain analogs have superior bactericidal activity.

Bactericidal activities of sample solutions containing ADBAC and MEE were measured as a function of reaction 


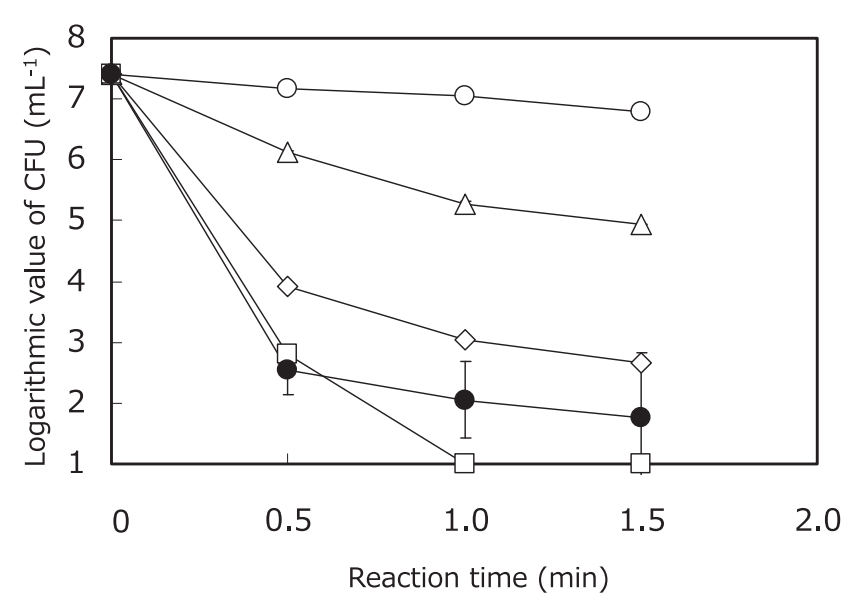

Fig. 3 Time course of decreasing viable bacterial counts of $E$. coli in a solution containing ADBAC with/without MEE.

$\bigcirc$ : ADBAC $3 \mu \mathrm{M}, \triangle$ : ADBAC $6 \mu \mathrm{M}, \diamond$ : ADBAC $9 \mu \mathrm{M}, \square$ : ADBAC $12 \mu \mathrm{M}, 0$ : ADBAC 3 $\mu \mathrm{M}$ with $\mathrm{C} 10 \mathrm{EO} 41 \mathrm{mM}$.

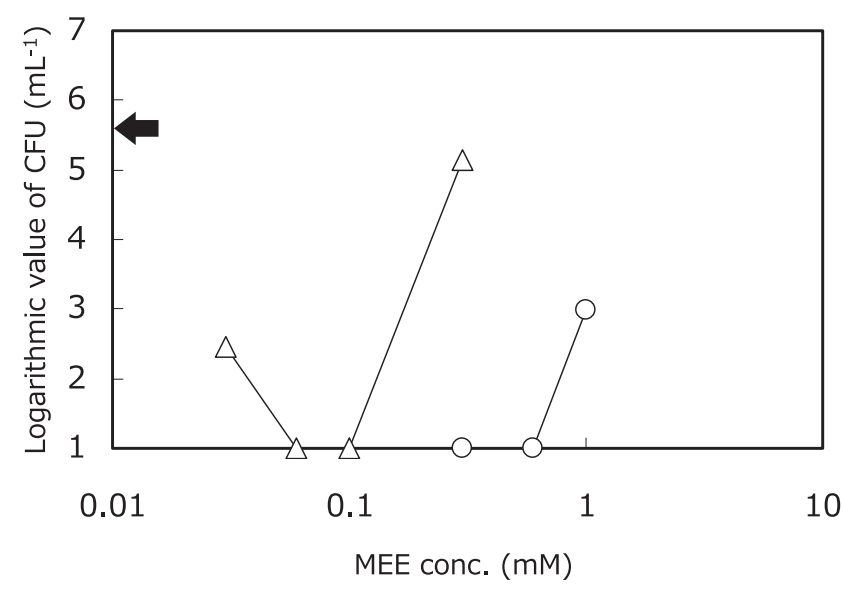

Fig. 4 Reduction in viable bacterial counts in a solution containing $1 \mu \mathrm{M}$ ADBAC and MEE with $5.7 \mathrm{log}$ $\mathrm{CFU} / \mathrm{mL}$ of $S$. aureus.

$\bigcirc: \mathrm{C} 10 \mathrm{EO} 4, \triangle$ : C12EO5. Arrow represents viable bacterial counts of $5.7 \log \mathrm{CFU} / \mathrm{mL}$ in a solution containing $1 \mu \mathrm{M}$ ADBAC without MEE.

time. As shown in Fig. 3, $7.4 \log$ CFU/mL of $E$. coli was added to each sample solution and the sample solution containing $3 \mu \mathrm{M}$ ADBAC without MEE exhibited viable bacterial counts of $6.8 \mathrm{log} \mathrm{CFU} / \mathrm{mL}$ at $1.5 \mathrm{~min}$. Another sample solution containing $3 \mu \mathrm{M}$ ADBAC and $1 \mathrm{mM}$ C10EO4 demonstrated viable bacterial counts of $2.5 \mathrm{log}$ $\mathrm{CFU} / \mathrm{mL}$ at $0.5 \mathrm{~min}$ and $1.8 \log \mathrm{CFU} / \mathrm{mL}$ at $1.5 \mathrm{~min}$. Three micromolars ADBAC containing $1 \mathrm{mM} \mathrm{C10EO4} \mathrm{exhibited}$ greater bactericidal activity than $9 \mu \mathrm{M}$ ADBAC. Therefore, it is suggested that $\mathrm{C} 10 \mathrm{EO} 4$ increased the bactericidal activity of ADBAC to more than 3 -fold.

The bactericidal activity of ADBAC containing MEE was

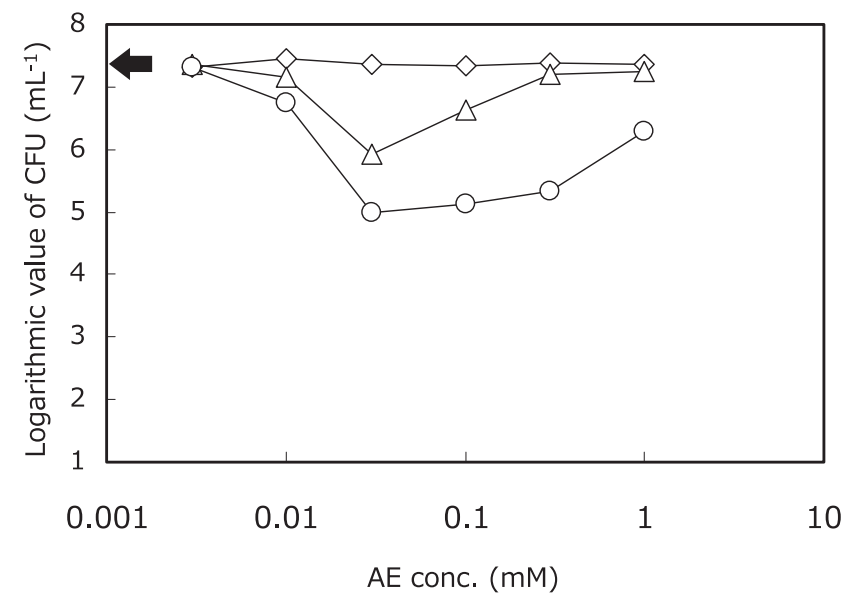

Fig. 5 Reduction in viable bacterial counts in a solution containing $2 \mu \mathrm{M}$ ADBAC and AE having different EO adduct numbers with $7.4 \log \mathrm{CFU} / \mathrm{mL}$ of E. coli.

$\bigcirc$ : EMALEX 703, $\triangle$ : EMALEX 715, $\diamond$ : EMALEX 750. Arrow represents viable bacterial counts of $7.4 \log \mathrm{CFU} / \mathrm{mL}$ in a solution containing $2 \mu \mathrm{M}$ ADBAC without MEE.

also measured against $S$. aureus. As shown in Fig. 4, 6.9 $\log \mathrm{CFU} / \mathrm{mL}$ of $S$. aureus were added to each sample solution. Reference solution containing $1 \mu \mathrm{M}$ ADBAC without MEE exhibited viable bacterial counts of $5.7 \log \mathrm{CFU} / \mathrm{mL}$. On the other hand, each sample solution containing C10EO4 or C12EO5 exhibited a decline in viable bacterial counts below $1.0 \log \mathrm{CFU} / \mathrm{mL}$ in the vicinity of CMC, 0.3-0.6 mM for C10EO4 and 0.06-0.1 mM for C12EO5. MEE showed an increase in bacterial death in the vicinity of CMC against not only $E$. coli as the gram-negative bacteria but also $S$. aureus as the gram-positive bacteria. Several nonionic surfactants also revealed reductions in MIC against other bacteria such as Pseudomonas aeruginosa and Salmonella enterica ${ }^{2,6)}$. The improvement in bactericidal activity with nonionic surfactants is observed against many types of bacteria. The cell wall of gram-negative bacteria is different from that of gram-positive bacte$\mathrm{ria}^{22)}$. The outer membrane of the cell wall, which is constructed principally from lipopolysaccharides, is present in gram-negative bacteria but not in gram-positive bacteria. It is believed that MEE molecules affect a cell membrane existing inside the outer membrane because the cell membrane regulates permeability of certain chemical reagents $^{23)}$.

\subsection{Bactericidal activity with $\mathrm{AE}$}

To measure cell viability, $7.4 \log \mathrm{CFU} / \mathrm{mL}$ of $E$. coli was added to each sample solution containing $2 \mu \mathrm{M}$ ADBAC and $\mathrm{AE}$. Figure 5 shows that a reference solution containing $2 \mu \mathrm{M}$ ADBAC without $\mathrm{AE}$ exhibited viable bacterial 
counts of $7.4 \log \mathrm{CFU} / \mathrm{mL}$. Sample solution containing 0.03 mM EMALEX 703 and EMALEX 715 had viable bacterial counts of 5.0 CFU/mL and 6.0 CFU/mL, respectively. Conversely, sample solution containing EMALEX 750 demonstrated no reduction in viable bacterial counts compared with a reference solution. Other sample solutions containing approximately the $\mathrm{CMC}$ of each $\mathrm{AE}$ (without $\mathrm{ADBAC}$ ) exhibited viable bacterial counts above $6.4 \log \mathrm{CFU} / \mathrm{mL}$.

EMALEX 703 and EMALEX 715 also showed enhanced bacterial death in the vicinity of their estimated CMC. Lowering the $\mathrm{EO}$ adduct number of $\mathrm{AE}$ further augmented the bactericidal activity. These results are similar to those observed with MEE as shown in Fig. 2. Nonionic surfactants with $\mathrm{EO}$ and oxypropylene groups also showed increase in the bactericidal activity, and Tween 80 with EO decreased $\mathrm{MIC}^{2,5)}$. It can be concluded that some nonionic surfactants with EO have a broad capacity to enhance bactericidal activity.

Nonionic surfactants with an alkyl group of $\mathrm{C} 12$ and EO adduct number of 5-20 are mainly included in a great number of cleaners for their washing properties ${ }^{8,11)}$. It is important to adjust the concentration of these nonionic surfactants within the vicinity of their CMC when used in cleaners with bactericides, such as ADBAC, as the bactericidal effects will be greatly improved. In addition, nonionic surfactants with lower EO adduct numbers should be used in cleaners.

\subsection{Analysis of fluorescence}

SYTO 9 and PI are fluorescence reagents that intercalate with DNA. These compounds have a specific fluorescence wavelength when they penetrate bacterial cells. The effect of MEE on bacterial cell body permeability was measured using SYTO 9 and PI. Figure 6 shows that sample solutions displayed approximately 50 units of fluorescence intensity at the start and the fluorescence intensity increases as the reaction time advances. The fluorescence intensity converges at 1,700 units at $600 \mathrm{~s}$. Each sample solution containing MEE exhibited higher fluorescence intensity than samples without MEE at the same reaction time. Reaction times achieved at 850 units, which is half-value of the maximum point of convergence for each sample ( $1 / 2$ constant time), were compared. The $1 / 2$ constant times were as follows: $\mathrm{C} 12 \mathrm{EO} 5(52 \mathrm{~s})<\mathrm{C} 10 \mathrm{EO} 4(71 \mathrm{~s})<\mathrm{C} 12 \mathrm{EO} 15$ (86 s) < without MEE (149 s) under the conditions containing $0.05 \mathrm{mM} \mathrm{MEE}$, and $\mathrm{C} 10 \mathrm{EO} 4(30 \mathrm{~s})<\mathrm{C} 12 \mathrm{EO} 5(86 \mathrm{~s})<$ C12EO15 (93 s) < without MEE (149 s) under the conditions containing $0.5 \mathrm{mM}$ MEE. Conversely, sample solutions containing PI showed no increase in fluorescence under the same conditions.

While SYTO 9 penetrates cell membranes of viable bacterial cells, PI does not. PI stains dead bacteria in which cell membranes are destroyed. We were able to distinguish viable bacterial cells from the dead cells using these re-

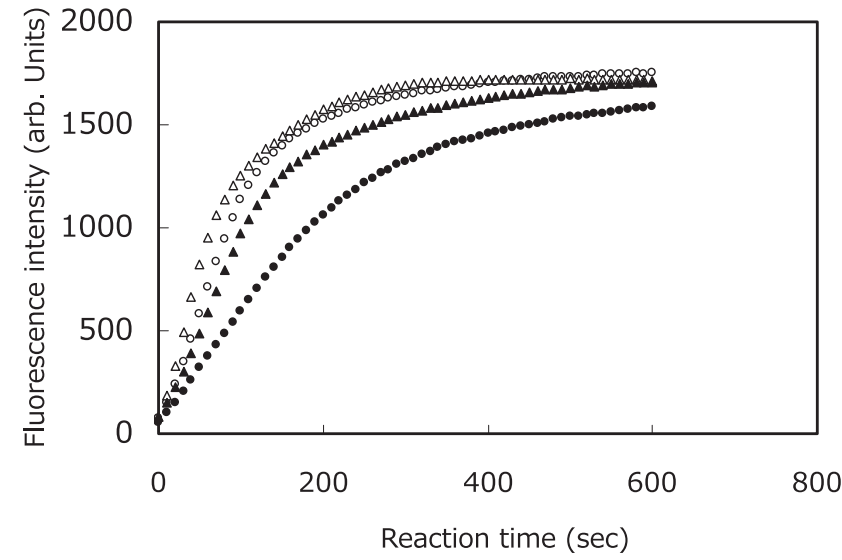

Fig. 6 Time course of fluorescence intensity of sample solutions containing OD 0.3 of E. coli and 0.25 $\mu \mathrm{M}$ SYTO 9 with/without $0.05 \mathrm{mM}$ MEE at $25^{\circ} \mathrm{C}$

$\bigcirc: \mathrm{C} 10 \mathrm{EO} 4, \triangle \mathrm{C} 12 \mathrm{EO} 5, \boldsymbol{\Delta}: \mathrm{C} 12 \mathrm{EO} 15$, none, $\lambda \mathrm{ex}=480 \mathrm{~nm}, \lambda \mathrm{em}=500 \mathrm{~nm}$

agents $^{24,25)}$. Both reagents work within minutes, and we were able to determine penetration of these dyes in bacterial cells in a solution containing MEE. SYTO 9 was added to a cell suspension containing MEE and each sample solution showed a shorter (by half) constant time than the reference sample solution containing no MEE. Moreover, no samples increased the fluorescence intensity of PI. These results suggest that MEE molecules have an effect on the cell membrane of viable bacterial cells, which enables easy penetration without destroying the cell membrane.

Decreasing the EO adduct number of MEE reduced the constant time by half. It is remarkable that MEE with low EO adduct numbers actually improves bactericidal activity and increases the velocity of the fluorescence intensity. Increased penetration of the bacterial cell membranes has an effect on bactericidal activity. C12EO5 showed the shortest $1 / 2$ constant time in $0.05 \mathrm{mM}$ of each MEE, and C10EO4 showed it in $0.5 \mathrm{mM}$ of each MEE. The $1 / 2$ constant times at each concentration of C10EO4 were as follows: $1 \mathrm{mM}(21$ s) $<0.5 \mathrm{mM}(30 \mathrm{~s})<0.05 \mathrm{mM}(71 \mathrm{~s})<$ without $(149 \mathrm{~s})$. Increasing concentrations of C10EO4 had a more effective response. These results indicate that $\mathrm{C} 10 \mathrm{EO} 4$ required higher CMC concentrations than C12EO5 to be able to penetrate the bacterial cell membrane.

\subsection{Zeta potentials}

Zeta potentials in each sample solution containing MEE were measured. ADBAC from a range of $0-0.1 \mathrm{mM}$ was added to each sample solution containing $1 \mathrm{mM}$ MEE, which was above CMC. Reference solutions containing 1 $\mathrm{mM}$ MEE without ADBAC exhibited $-13 \mathrm{mV}$ to $-36 \mathrm{mV}$ of zeta potential, and sample solutions containing $1 \mathrm{mM}$ MEE and 0.01-0.1 mM ADBAC exhibited a higher voltage 


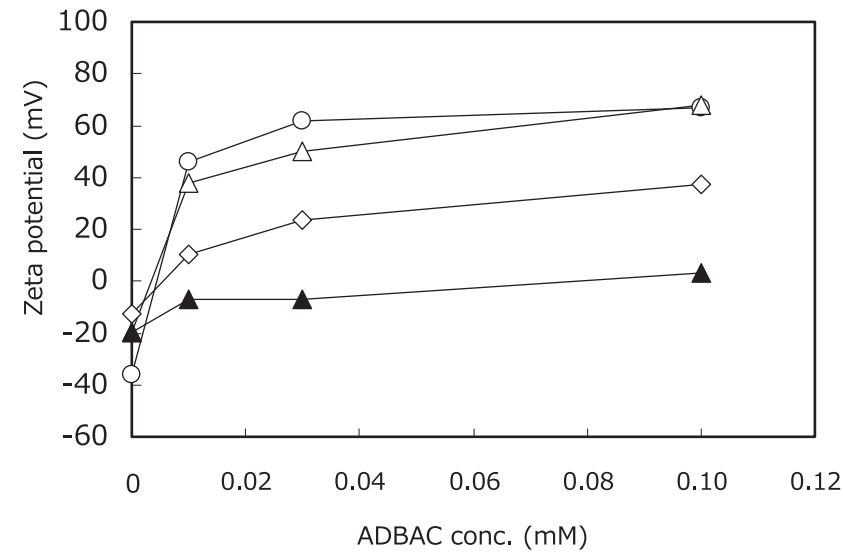

Fig. 7 Zeta potentials of sample solutions containing ADBAC and MEE.

$\bigcirc: \mathrm{C} 10 \mathrm{EO} 4, \triangle: \mathrm{C} 12 \mathrm{EO} 5, \diamond: \mathrm{C} 14 \mathrm{EO} 6$, $\mathrm{C} 12 \mathrm{EO} 15$

than the reference solutions (Fig. 7). A reduction in the EO adduct number or carbon number of the alkyl group of MEE appeared to result in higher voltage with $0.01 \mathrm{mM}$ ADBAC than the reference solution as follows: C10EO4 (46 $\mathrm{mV})>\mathrm{C} 12 \mathrm{EO} 5(38 \mathrm{mV})>\mathrm{C} 14 \mathrm{EO} 6(11 \mathrm{mV})>\mathrm{C} 12 \mathrm{EO} 15$ $(-7 \mathrm{mV})$. Furthermore, an increase in the concentration of ADBAC resulted in an increased zeta potential.

In this study, $0.1 \mathrm{mM}$ of $\mathrm{ADABC}$ was added to the sample solutions and this concentration was below its CMC. However, MEE was also added at a concentration above CMC. It appears likely that ADBAC molecules were incorporated into MEE micelles and mixed micelles were formed. Decreasing the carbon number of the alkyl chain and EO chain length of MEE resulted in higher positive zeta potentials. This situation is schematically shown in Fig. 8. We assume that ADBAC molecules tend to expose their cationic headgroups to the aqueous phase as a result of the decreased hydrocarbon chain lengths and EO units

\section{C10EO4}

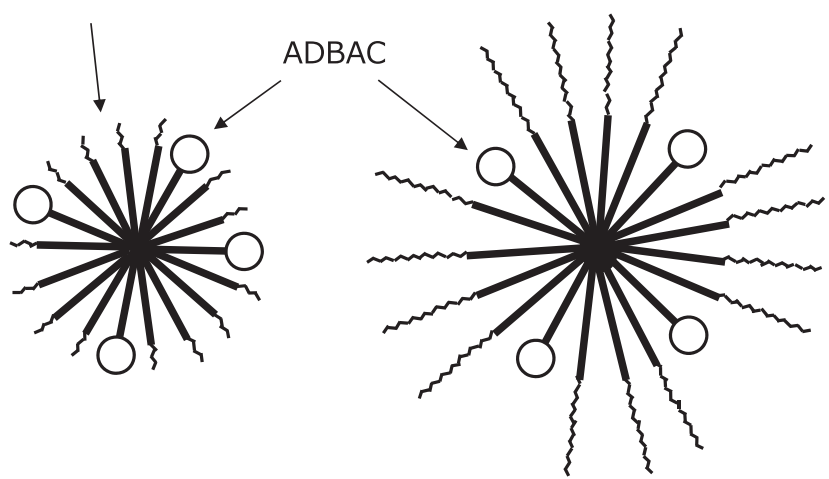

Fig. 8 Image of mixed micelle system constructed by both, MEE and ADBAC.

Left: with C10EO4, right: with C12EO15 of MEE. The enhanced bactericidal activity observed above in the CMC of MEE in Fig. 2 may result from the presence of the cationic headgroups on the micelle surface.

Rauwela et al. founded that sample solutions containing nonionic surfactants with low carbon numbers in the alkyl group and low EO adduct numbers showed bactericidal activity with $\mathrm{DDAC}^{26)}$. They showed that the bactericidal activity was influenced by the appearance of the cationic region of DDAC molecules in mixed micelles using pulsefield nuclear magnetic resonance. In this study, we show a relationship between the zeta potential of the micelles and the bacterial activity. It is suggested that increasing the zeta potential of micelles improves the probability of the attachment of ADBAC molecules to the anionic regions of bacterial cell bodies such as proteins and phospholipids.

\subsection{Transferred ADBAC to bacterial cells}

It is well known that some cationic surfactant molecules transfer to bacterial cells in aqueous solutions ${ }^{27)}$. Transferred cationic surfactants were measured by determination of cationic surfactants remaining in solutions after removal of bacterial cells using filtration. The concentration of ADBAC transferred to bacterial cells (in the absence and presence of MEE) was measured according to a previously described method ${ }^{28)}$. Almost all of ADBAC molecules that exist in water solvent without MEE micelles were transferred to bacterial cells (Fig. 9). MEE showed a tendency to inhibit the transfer of ADBAC molecules. However, decreasing the carbon and EO adduct numbers of MEE showed transfer of ADBAC molecules. The results are comparable to the zeta potential results shown in Fig. 7.

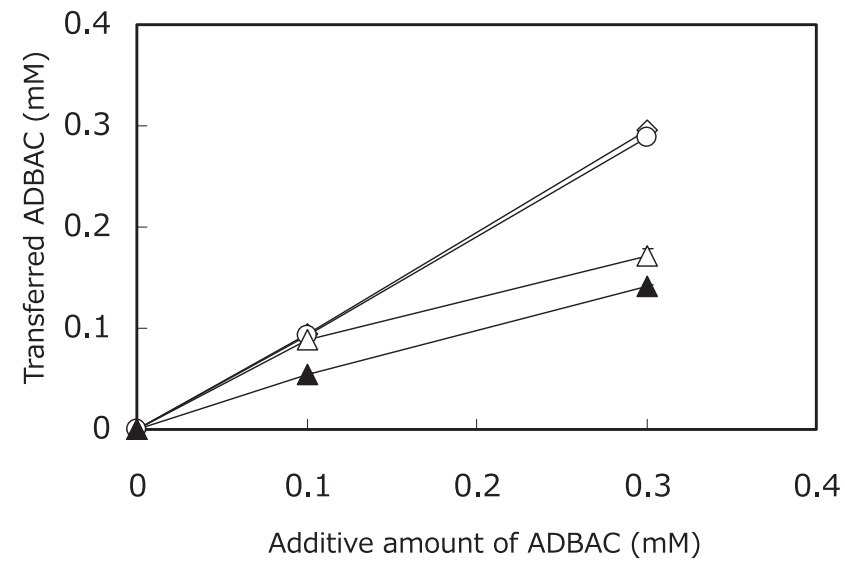

Fig. 9 Proportion of ADBAC transferred into bacterial cells in solutions containing MEE.

$\bigcirc:$ C10EO4, $\triangle$ : C12EO5, $\Delta:$ C12EO15, $\diamond:$ none. OD 1 of $E$. coli was added in a solution containing variable concentrations of ADBAC with $1 \mathrm{mM}$ MEE. Transferred ADBAC was calculated from a concentration of a filtrated solution after centrifugation. 
It is believed that increasing the appearance of the cationic region of ADBAC molecules in mixed micelles will increase adsorption of ADBAC molecules to the anionic region in bacterial cells.

\section{CONCLUSION}

Nonionic surfactants such as MEE and AE can either enhance or inhibit the bactericidal activity of ADBAC. When concentrations of MEE are lower than CMC the enhancing effect is dominant. In contrast, when the concentrations of MEE are higher than CMC an inhibitory effect is observed. Our results suggest that nonionic surfactants exert at least two abilities. One is the increase of permeability of bacterial cell membrane, and the other is the inhibition of adsorption on the bacterial cell membrane by micelle incorporation. Furthermore, decreasing the EO adduct number of nonionic surfactant or decreasing the carbon number of the alkyl group further improved bactericidal activity. It is also suggested that their nonionic surfactants increase the permeability of bacterial cell membrane, and reduce the inhibition of ADBAC adsorption onto the bactericidal cell membrane because of the incorporation of ADBAC cationic parts into the mixed micelles.

\section{ACKNOWLEDGMENTS}

We are grateful to Otsuka Electronics Corporation for support with the use of the zeta potential and particle size analyzer ELSZ-1000, and Nippon Nyukazai Corporation for providing the alkyl glycol ethers.

\section{References}

1) Russell, A. D.; Hugo, W. B.; Ayliffe, G. A. J. Princple and practice of disinfection, preservation and sterilization, 2nd edn., Blackwell Science Ltd., New Jersey, pp. 7-88(1992).

2) Schmolka, I. R. The synergistic effects of nonionic surfactants upon cationic germicidal agents, J. Soc. Cosmet. 24, 577-592 (1973).

3) Goto, A.; Nihei, M.; Endo, F. Solubilization of methylparaben in nonionic surfactant micelles in aqueous solution, J. Phys. Chem. 84, 2268-2272(1980).

4) Attwood, D.; Florence, A. T. Monomer concentrations in micellar drug systems, J. Pharm. Pharmacol. 23 Dec, 242-243 (1971).

5) Aoki, M.; Kamada, A.; Matsumoto, M.; Hasegawa, K.; Isa, Y. Application of surface active agents to pharmaceutical preparation. III. The influence of non-ionic surface on the activity of sparingly water-soluble fun- gicides. Yakugaku zasshi 77, 1071-1075(1957).

6) Gershenfeld, L.; Stedman, R. L. The potential effects of various compounds on the antibacterial activities of surface active agents. Amer. J. Pharm. 121, 249-266 (1949).

7) Gomi, M.; Osaki, Y.; Mori, M.; Sakagami, Y. Synergistic bactericidal effects of a sublethal concentration of didecyldimethylammonium chloride (DDAC) and low concentrations of nonionic surfactants against Staphylococcus aureus. Biocontrol Science 17, 175-181 (2012).

8) Bajpai, D.; Tyagi, V. K. Laundry detergents: an overview. J. Oleo Sci. 56, 327-340(2007).

9) Tobe, S.; Kumata, N.; Takahashi, K.; Watanabe, T.; Yoshimura, H.; Kikukawa, M. Bactericidal activity of bleach activators, alkylacyloxybenzoic acids and alkylacyloxybenzene sulfonates. Bokin Bobai 35, 269-277 (2007).

10) Fujiwara, M.; Miyake, M.; Hama, I. Phase behavior of methoxypolyoxyethylene dodecanoate as compared to polyoxyethylene dodecyl ether and polyoxyethylene methyl dodecyl ether. Coll. Polymer Sci. 272, 797802 (1994).

11) Zimoch, J.; Hreczuch, W.; Trathnigg, B.; Meissner, J.; Bialowas, E.; Szymanowski, J. Detergency and dynamic surface tension reduction of oxyethylated fatty acid methyl esters. Tenside, surfactants, detergents 39, 8-16 (2002).

12) Bialowas, E.; Szymanowski, J. Catalysts for oxyethylation of alcohols and fatty acid methyl esters. Ind. Eng. Chem. Res. 43, 6267-6280(2004).

13) Tobe, S.; Majima, T.; Terabayashi, T. Jpn. Pat. 28942 (2014).

14) Gray, L. M.; Scheibel, J. J.; Vinson, P. K.; Binski, C. J. WO Pat., 053906 (2003).

15) Os, N. M.; Haak, J. R.; Rupert, L. A. M. Physico-chemical properties of selected anionic, cationic and nonionic surfactants, Elsevier Amsterdam pp. 212222 (1993).

16) Takenaka, S.; Iwaku, M.; Hoshino, E. Artificial Pseudomonas aeruginosa biofilms and confocal laser scanning microscopic analysis. J. Infect. Chemother. 7, 87-93 (2001).

17) Taylor, I. W.; Milthorpe, B. K. An evaluation of DNA fluochromes, staining techniques, and analysis for flow cytometry. I. unperturebed cellpopulations. J. Histochem. Cytochem. 28, 1224(1980).

18) Ray, G. B.; Chakraborty, I.; Moulik, S. P. Pyrene absorption can be a convenient method for probing critical micellar concentration (cmc) and indexing micellar polarity, J. Colloid and Interface Sci. 294, 248-254 (2006).

19) EN1040, Chemical disinfectants and antiseptics. Quantitative suspension test for the evaluation of ba- 
sic bactericidal activity of chemical disinfectants and antiseptics. Test method and requirements (phase 1), 2006.

20) Japanese Pharmacopoeia, 6th edn., Ministry of Health, Labour and Welfare, Tokyo (2011).

21） Ding, W.; Izumisawa, T.; Hattori, Y.; Qi, X.; Kitamoto, D.; Maitani, Y. Non-ionic surfactant modified cationic liposomes mediated gene transfection in vitro and in the mouse lung, Biol. Pharm. Bull. 32, 311-315 (2009).

22) Hiramatsu, K. Microbiology, 11th edn., Igakushoion, Tokyo, pp. 66-72 (2012).

23) Porter, R. S.; Kaplan, J. L. ed. The Merck Manual for health care professionals, 19th edn., http://www. merckmanuals.com/professional/clinical_pharmacology/pharmacokinetics/drug_absorption.html?qt=cell\% 20membrane\&alt=sh.

24) Lehtinen, J.; Nuutila, J.; Lilius, E. M. Green fluorescent protein-propidium iodide (GFP-PI) based assay for flow cytometric measurement of bacterial viability, Cytom- etry A 60, 165-172 (2004).

25) Stocks, S. M. Mechanism and use of the commercially available viability stain, BacLight, Cytometry A 61, 189-195 (2004).

26) Rauwela, G.; Leclercqb, L.; Criqueliona, J; Aubry, J.M.; Nardello-Ratajb V. Aqueous mixtures of di-n-decyldimethylammonium chloride/polyoxyethylene alkyl ether: dramatic influence of tail/tail and head/head interactions on co-micellization and biocidal activity. $J$. Colloid and Interface Sci. 374, 176-186 (2012).

27) Nakata, K.; Tsuchido, T.; Matsumura, Y. Antimicrobial cationic surfactant, cetyltrimethylammonium bromide, induces superoxide stress in Escherichia coli cells. $J$. Appl. Microbiol. 110, 568-579(2011).

28) Yuan, X. Z.; Ren, F. Y.; Zeng, G. M.; Zhong, H.; Fu, H. Y.; Liu, J.; Xu, X. M. Adsorption of surfactants on a Pseudomonas aeruginosa strain and the effect on cell surface lypohydrophilic property. Appl. Microbiol. Biotechnol. 76, 1189-1198(2007). 